\title{
Relationship between organic matter humification and bioavailability of sludge-borne copper and cadmium during long-term sludge amendment to soil
}

\author{
Hongtao Liu \\ Institute of Geographic Sciences and Natural Resources Research, Chinese Academy of Sciences, Beijing 100101, PR China
}

\section{H I G H L I G H T S}

- Organic matter in sludge degraded with time goes after sludge was recycled to soil.

- DP in sludge is well coupled with incremental uptaken fraction of its borne copper.

- Profiles of Cadmium fractions in sludge exhibit an independent manner.
G R A P H I C A L A B S T R A C T

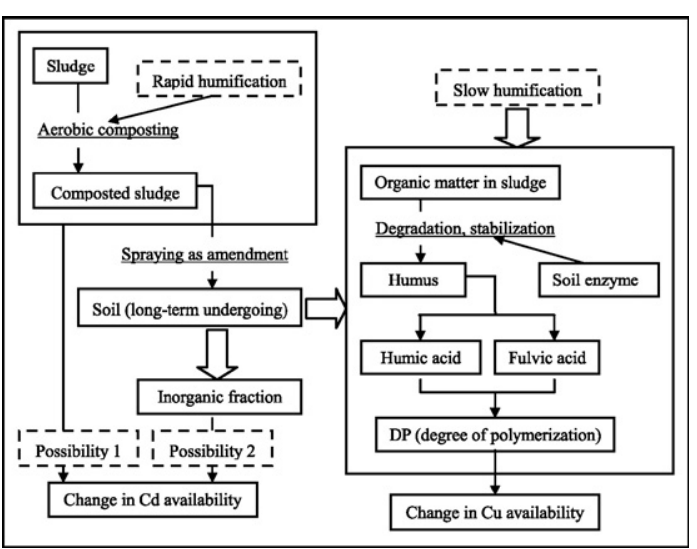

\section{A B S T R A C T}

Recycling of sludge as soil amendment poses certain risk of heavy metals contamination. This study investigated the relationship between organic matter in composted sludge and its heavy metals bioavailability over 7 years. Periodic monitoring indicated a gradual increase in organic matter degradation, accompanied by changing degrees of polymerization, i.e., ratio of humic acid (HA)/fulvic acid (FA) coupled with incremental exchangeable fraction of copper $\mathrm{Cu}$ in sludge, with a growing rate of $74.7 \%$, rather than that in soil. However, cadmium (Cd) in composted sludge exhibited an independent manner. Linear-regression analysis revealed that the total proportion of the $\mathrm{Cu}$ active fraction (exchangeable plus carbonate bound) was better correlated with the degree of polymerization (DP) and humification ratio (HR) than the degradation ratio of organic matter. Overall, amount of uptaken Cu was more dependent on the humification degree of organic matter, especially the proportion of HA in humus.

(c) 2016 Elsevier B.V. All rights reserved. 


\section{Introduction}

There are currently many ways to reuse sewage sludge, including coincineration with cement, anaerobic digestion to produce methane, and carbonization to enable use in building materials. Among available treatment and disposal methods, application to soil as an amendment or fertilizer is regarded as a good option because it uses little energy and results in only minor secondary pollution of the environment (Liu and Zhang, 2013; Yoshida, et al., 2013; Mills et al., 2014). Phyto-nutrients in sewage sludge, such as nitrogen, phosphorus and organic matter, can be adequately recycled and valorized. However, this method results in introduction of contaminants to the soil, such as organic contaminants and heavy metals. Although organic contaminants gradually degrade to some extent when sludge is applied to soil (Butler et al., 2012; Rhind et al., 2013; Stanczyk-Mazanek et al., 2009; Wu et al., 2011), levels of heavy metals in sludge do not decrease after soil application. Indeed, heavy metals are the most important environmental concern associated with the application of sludge to soil. Therefore, standards have been set to limit the amount of heavy metals in sludge that is applied to soil. However, current standards limit total heavy metals rather than the active fraction (General Administration of Quality Supervision, Inspection and Quarantine of China, and Standardization Administration of China, 2009; Ministry of Housing and Urban-Rural Development of China, 2009, 2011; United States Environmental Protection Agency, 1993), especially the forms characterized as bioactivity of heavy metal, which can objectively reflect the its amounts from sludge to edible tissues uptaken by crop when sludge was reused as an amendment. In other words, the abundance of total heavy metals cannot account for the potential caused by the proportion of mobile heavy metals in sludge.

From 2007 to 2014, many studies have reported the heavy metals risk associated with the amendment of sludge to soil (Alcantara et al., 2009; Antoniadis et al., 2007; Brazauskiene et al., 2008; Carbonell et al., 2009; Lag-Brotons et al., 2014; Oladeji et al., 2012; Yeganeh et al., 2010). However, there is certain boundedness on the conclusions obtained by these researchers mentioned above. For example, (i) the risk has only been assessed by monitoring the results of heavy metals at one point in time after application of sludge to soil rather than consecutive detection. (ii) There is consensus regarding the relationship between potential risk and heavy metals bioavailability, but rarely involving organic matter. (iii) The relationship was investigated; however, the results were due to the simulating and laboratory level, in other words, in the absence of the impact by natural process and the support by the data obtained in field condition.

This study elaborated the connection between changes in organic matter transformation and heavy metal bioavailability in sludge that was applied to soil as an amendment over 7 years based on experimental results under field conditions. Significant differences were found in the shift of $\mathrm{Cu}$ and $\mathrm{Cd}$ from the inactive fraction to the active fraction in sludge, and the results implied that $\mathrm{Cu}$ is more susceptible to the transformation between organic matter and humus.

\section{Materials and methods}

Sludge used in this study was collected from a municipal wastewater treatment plant located in Qinhuangdao (Hebei Province, China), then mixed with wheat straw (bulking agent) at a ratio of 5:4 by volume. The resulting mixture was composted in a static forced aeration device for 28 days, after which the composted sludge was placed in a storehouse and allowed to age for 60 days. The sludge was then transported by road from Qinghuangdao to Beijing. The physicochemical properties of the sludge compost are shown in Table 1. The experiment was performed for 7 consecutive years (2008-2014) at an experimental site located on the north side of Baima Road in Shunyi District, Beijing, which is a sod base of the Chinese Seed company. First, the soil was turned over twice, after which the sludge was sprayed onto the soil at depths of 8-
Table 1

Main physicochemical properties of soil and sludge used in the experiment.

\begin{tabular}{lrr}
\hline Indicator & Soil & Sludge \\
\hline Moisture (\%) & \multicolumn{1}{c}{21} & 44 \\
Organic matter content (\%) & 18.1 & 17.5 \\
Cu content $\left(\mathrm{mg} \cdot \mathrm{kg}^{-1}\right)$ & 785.4 & 1345.6 \\
Cd content $\left(\mathrm{mg} \cdot \mathrm{kg}^{-1}\right)$ & 1.3 & 2.9 \\
Total extractable carbon $\left(\mathrm{g} \cdot \mathrm{kg}^{-1}\right)$ & 28.6 & 61.1 \\
Humic acid carbon $\left(\mathrm{g} \cdot \mathrm{kg}^{-1}\right)$ & 1.2 & 26.4 \\
Fulvic acid carbon $\left(\mathrm{g} \cdot \mathrm{kg}^{-1}\right)$ & 0.9 & 22.7 \\
\hline
\end{tabular}

$10 \mathrm{~cm}$ at an amended dose of $90 \mathrm{Mg} \cdot \mathrm{ha}^{-1}$ in early October 2008 . The experimental region was designed and divided into two plots (200 m $\times 20$ m every plot), a treated one and another un-amended plot as a comparative background. A nylon mesh fabric ( $50 \mathrm{mesh} \cdot \mathrm{ft} .^{-2}$ ) was employed to keep unmixed and amended soil and sludge relatively separate without impacting the interaction between soil and sludge. Periodic sampling was conducted in mid-October every year, and each plot was sampled repeatedly six times. Following sampling, the location was marked with a flag to enable it to be resampled. All collected soil and sludge samples were brought back to the laboratory for indicator analysis.

All samples were dried and passed through a 2-mm sieve. Ash content was determined by combustion at $550{ }^{\circ} \mathrm{C}$ for $8 \mathrm{~h}$. Organic matter was determined by subtraction of ash content, and total organic carbon was calculated as $58 \%$ of the organic matter (Zmora-Nahum et al., 2005). Total extractable carbon (TEC) content was obtained by extraction from the sample with $0.1 \mathrm{~mol} \cdot \mathrm{L}^{-1}$ of $\mathrm{Na}_{4} \mathrm{P}_{2} \mathrm{O}_{7}$ ( $\mathrm{pH}$ 9.7) using a sample: extraction ratio of 1:10 and subsequent colorimetric determination (Sims and Haby, 1971). An aliquot of the extract was acidified with $\mathrm{HCl}$ to $\mathrm{pH} 1.0$, left to stand for $24 \mathrm{~h}$ in a refrigerator for the complete precipitation of $\mathrm{HA}$, and then centrifuged. FA content was determined by measuring the $C$ content in the supernatant in the same way as explained above for TEC. HA content was calculated by subtracting the $\mathrm{C}$ content in the acidified supernatant from the TEC content. The HR percentage of HA and DP was calculated from these parameters as (TEC/ TOC) $\times 100$, HA/TOC $\times 100$ and HA/FA, respectively (Senesi, 1989).

The $\mathrm{Cu}$ and $\mathrm{Cd}$ fractions were analyzed by the Tessier Sequential Extraction method to determine the fractions in soil and sludge samples (Tessier et al., 1979; Zheng et al., 2007). Five solutions were generated successively: exchangeable $\left(1 \mathrm{~mol} \cdot \mathrm{L}^{-1} \mathrm{MgCl}_{2}, \mathrm{pH}\right.$ 7); carbonated bound ( $\left.1 \mathrm{~mol} \cdot \mathrm{L}^{-1} \mathrm{NaOAc} / \mathrm{HOAc}, \mathrm{pH} 5\right) ; \mathrm{Fe}-\mathrm{Mn}$ oxide bound (0.04 $\mathrm{mol} \cdot \mathrm{L}^{-1} \mathrm{NH}_{2} \mathrm{OH} \cdot \mathrm{HCl}$ in $25 \% \mathrm{HOAc}$ ); organically bound $\left(0.02 \mathrm{~mol} \cdot \mathrm{L}^{-1} \mathrm{HNO}_{3}\right.$ in $30 \% \mathrm{H}_{2} \mathrm{O}_{2}$, $\mathrm{pH} 2 ; 3.2 \mathrm{~mol} \cdot \mathrm{L}^{-1} \mathrm{NH}_{4} \mathrm{OAc}$ in $20 \%$ $\mathrm{HNO}_{3}$ ); residual (digested with concentrated $\mathrm{HNO}_{3}+\mathrm{HClO}_{4}$ ). To perform quality control, the samples of certified standard reference materials were simultaneously digested for soils and sludge (GSS-1) from the China National Standard Materials Center with the experimental samples. The concentrations of $\mathrm{Cu}$ and $\mathrm{Cd}$ were determined by flame atomic absorption spectrophotometry (ContrAA700, Jena, Germany). All figures were developed using OriginPro 8.0, and all data were analyzed using SPSS v.13.0. Linear regression, based on $p$-value $(p<0.05)$, was used to simulate the correlations between organic matter degradation, $\mathrm{HR}, \mathrm{DP}$ and $\mathrm{Cu}$ active fraction to explain their characteristics in sludge.

\section{Results}

\subsection{Tendency for organic matter degradation in soil and sludge}

Fig. 1 (A) and (B) display the organic matter and its degradation profile in soil over seven years, respectively. There was no significant fluctuation in organic matter content in soil from the beginning of sludge amendment to the end. Correspondingly, the degradation ratio of organic matter also exhibited no abrupt change, with a maximum increase of only 5.9\%. However, as shown in Fig. 1 (C) and (D), the content of 


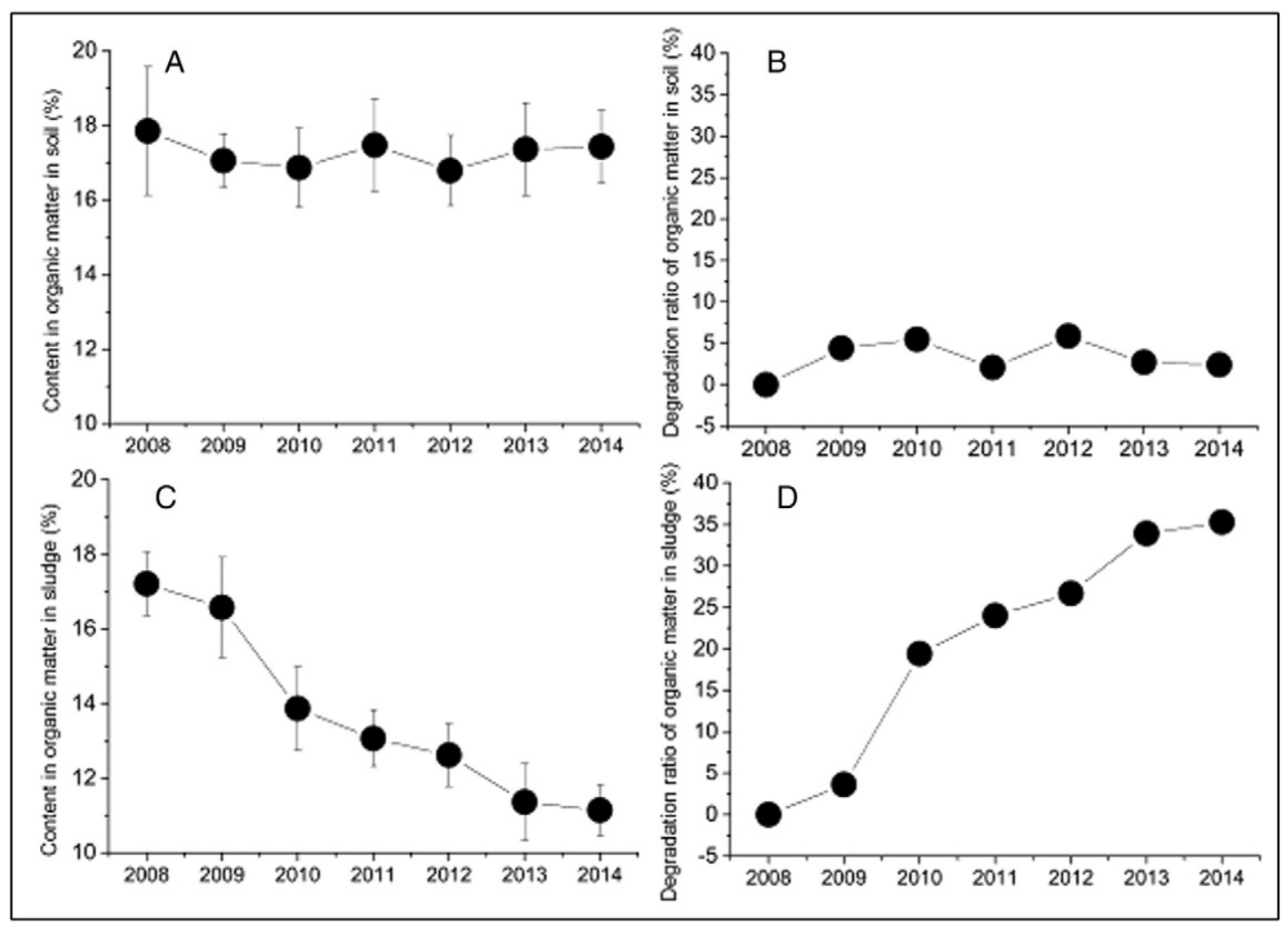

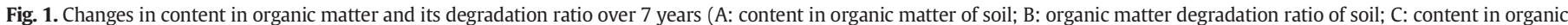
matter of sludge; D: organic matter degradation ratio of sludge).

organic matter in sludge decreased gradually with time from 2008 to 2014 , while the change in the degradation ratio of organic matter in sludge showed the inverse pattern. As shown in Fig. 1 (D), the degradation ratio increased to $3.6 \%$ in the second year, after which it was gradually elevated from $19.4 \%$ to $35.3 \%$, indicating that the majority of organic matter in sludge decomposed with the aid of soil enzymes and functional microorganisms.

\subsection{Change in humification ratio (HR) and degree of polymerization (DP) in soil and sludge}

After sludge was amended to the soil, the HR in soil showed no obvious change with time, with an initial value of $18.25 \%$ and a final value of $20.42 \%$ being observed (Fig 2. (A)). Conversely, the HR in sludge presented an increasing appearance from 2008 to 2014, with the maximum ratio reaching $28.37 \%$ (Fig. 2 (B)). These results are in accordance with those shown in Fig. 1, implying that most of degradable organic matter was converted to humus.

The degree of polymerization in soil and sludge was further analyzed. As shown in Fig. 3 (A), a similar tendency of DP in soil was observed compared with HR, ranging from $1.35 \%$ to $1.67 \%$. Additionally, there was an increasing trend in DP in sludge (Fig. 3 (B)) approaching that of the HR, implying that the humus converted from the organic material all repolymerized to stabilized macromolecule organic compounds, which usually function as regulators of soil or biosolids improvement.

\subsection{Change in bioavailability of $\mathrm{Cu}$ and $\mathrm{Cd}$ and their transformation among different fractions in soil and sludge}

As shown in Fig. 4, the levels of the five $\mathrm{Cu}$ fractions (exchangeable, carbonate bound, Fe/Mn-oxide bound, organically bound, residual) in soil all remained constant during the studied period. However, the proportion of the Cu exchangeable faction in sludge increased from $16.2 \%$ to
$28.3 \%$ with time accompanied by a gradual decline in the residual fraction. The total exchangeable plus carbonate bound fractions are usually regarded as the $\mathrm{Cu}$ active fraction, which can be taken up by plants. From this viewpoint, the level of the $\mathrm{Cu}$ active fraction increased with time.

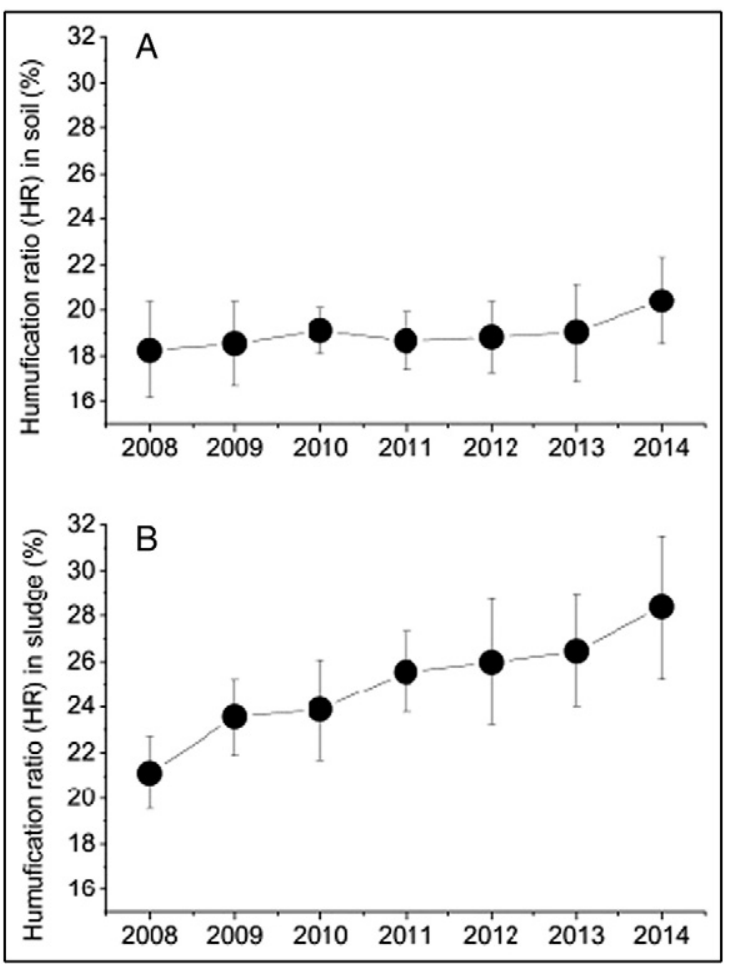

Fig. 2. Changes in humification ratio (HR) over 7 years (A: soil; B: sludge). 


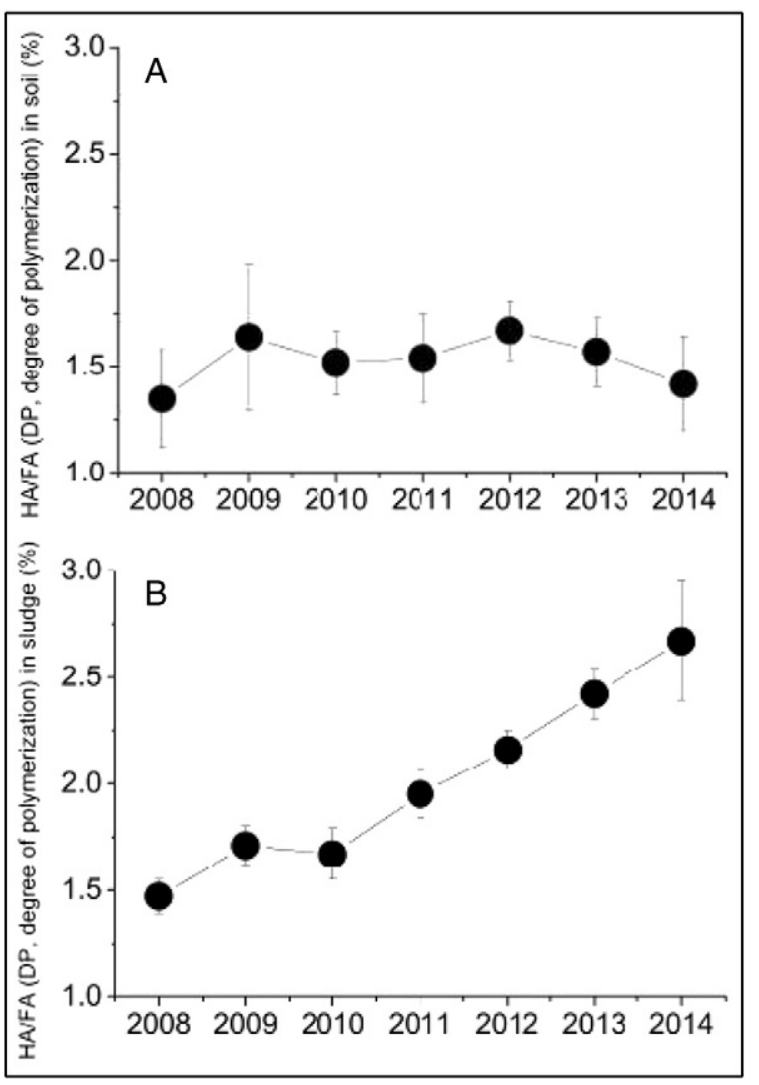

Fig. 3. Changes in degree of polymerization (DP) over 7 years (A: soil; B: sludge).

The levels of exchangeable $\mathrm{Cd}$ in both soil and sludge showed similar unchangeable tendencies as $\mathrm{Cu}$, although these changes seemed to be independent of time. These changes were clearly not associated with the changes in organic matter degradation, HR or DP. Moreover, the level of the Cd active fraction and residual fraction were also relatively stable from 2008 to 2014 (Fig. 5).

\subsection{4. Linear-regression analyses between the proportion in $\mathrm{Cu}$ active fractions and organic matter relative indicators}

Linear-regression analysis of the $\mathrm{Cu}$ active fraction and organic matter degradation revealed a determination coefficient of $\mathrm{R}^{2}=0.787$ $(p<0.05)$, while analysis of the $\mathrm{Cu}$ active fraction and HR revealed a determination coefficient of $\mathrm{R}^{2}=0.887(p<0.05$, as shown in Fig.6 (B)). Surprisingly, the determination coefficient between the $\mathrm{Cu}$ active fraction and DP was up to $\mathrm{R}^{2}=0.91(p<0.05$, as shown in Fig.6 (C)). These findings indicate that DP should reflect the level of active $\mathrm{Cu}$ more directly than organic matter degradation, even the HR.

\section{Discussion}

Previous reports showed that organic matter was involved in conversion of heavy metal fractions in sludge when it was added to soil for a relatively long duration. Accordingly, there are two theories regarding this regulation. One is known as the 'time-bomb' viewpoint, which indicates that the change in bioavailability of heavy metals in sludge accounted for the bondability of organic matter to different heavy metal fractions (Bergkvist et al., 2005; McBride, 2003; Stietiya and Wang, 2011). In this theory, the proportion of active fractions of heavy metal increases after sludge is recycled to soil as the sludge is gradually degraded. Another concept is the 'Protect' theory, in which the bioavailability of heavy metals is controlled by the inorganic fraction in sludge, which is adsorbed onto soil particles in an invariable ratio

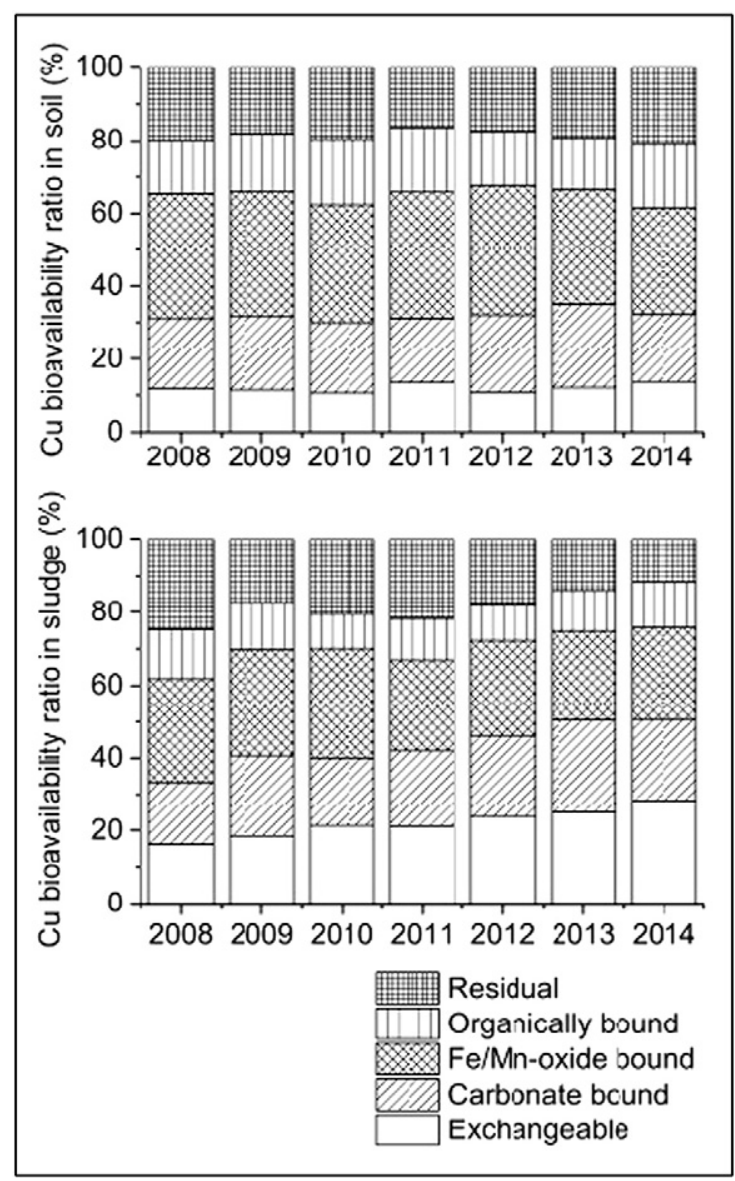

Fig. 4. Changes in Cu bioavailability ratio in soil and sludge.

once sludge is added to soil as an organic fertilizer. Therefore, changes in the active form of heavy metal in sludge and its release potential to soil are independent of time (Frost and Ketchum, 2000; McBride, 2003).

It is generally believed that organic matter in sludge decreases with time after application to soil (Diagboya et al., 2015; Lu et al., 2014; Stietiya and Wang, 2011). This is a consequence of stabilization and humification (Fernández et al., 2007). In the presence of related soil enzymes, small molecules of organic matter are gradually transformed to complicated and stable macromolecular humus. Based on the results obtained in this study, the incremental change in the proportion of the $\mathrm{Cu}$ active fraction was positively associated with organic matter degradation, but not as closely as with HR, especially DP. In other words, a more accurate indicator can be employed to characterize the incremental change in $\mathrm{Cu}$ active fraction on the basis of the affirmative conclusion that uptaken $\mathrm{Cu}$ can be reflected by organic matter degradation (Mamindy-Pajany et al., 2014). Accordingly, the DP of sludge, which is responsible for the development of aggregate structure, also induces transformation of the $\mathrm{Cu}$ inactive fraction to the active fraction, to some extent, implying that the fraction of $\mathrm{Cu}$ is mainly regulated by sludge-borne micromolecular organic matters prior to its stabilization. Incremental HA, which functions as strong aggregation, weakens the affinity to $\mathrm{Cu}$, accounting for the difference in competitive sorption caused by functional groups (Adani and Tambone, 2005; Oliver et al., 2005). In addition, high HA in sludge can be characterized by the lower acidic functional group content relative to soil (Pedra et al., 2008), further confirming that control of $\mathrm{Cu}$ was lost when sludge was mixed together with soil. Therefore, the degradation ratio of organic matter was the only superficial indicator that could be used to predict the proportion of the active fraction in the total amount of $\mathrm{Cu}$, indicating that DP would be a more effective and accurate indicator. Sludge-borne organic matter stabilized gradually after application, and its amount in the 


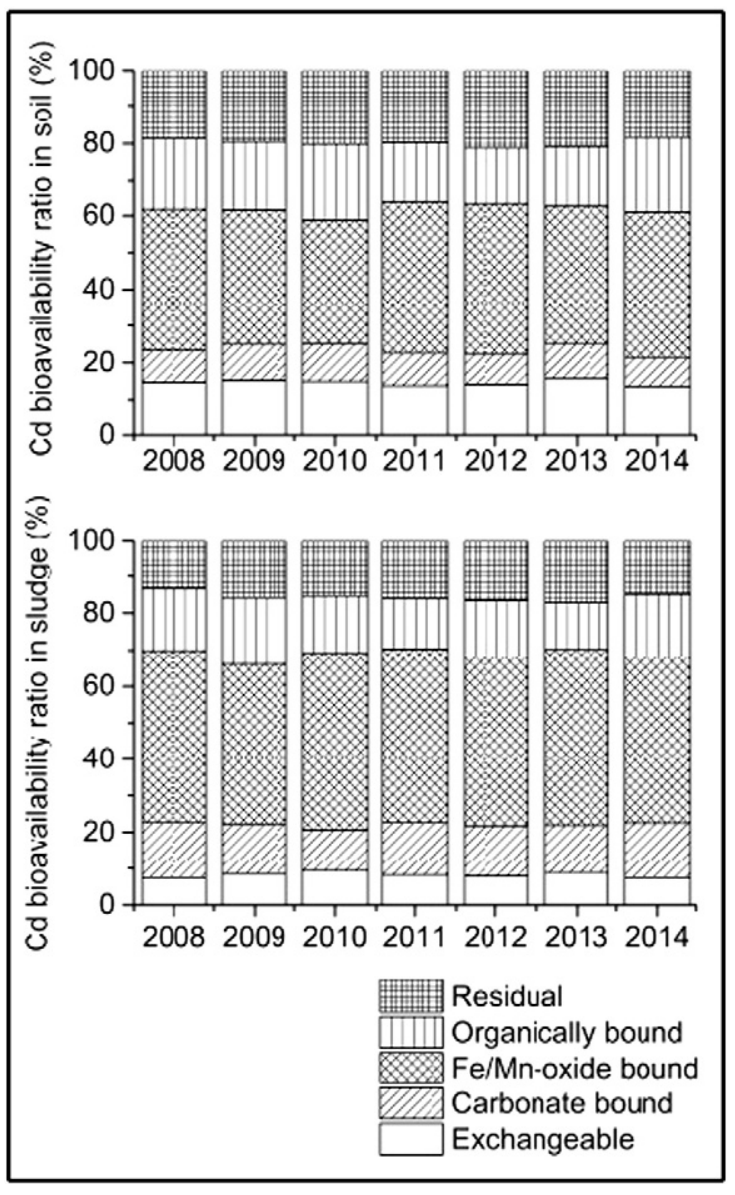

Fig. 5. Changes in Cd bioavailability ratio in soil and sludge.

humified fraction increased. Consequently, the uptaken $\mathrm{Cu}$, which is defined as the phyto-absorbed fraction, also presented an increasing tendency. This conclusion is referential and helpful to revise or fill the hole in the limit-value of heavy metal issued in the standard, which is responsible for controlling environmental risk from recycling of sludge to soil. Active fraction of some specific heavy metal should be taken to the consideration, particularly the organic matter profile, such as DP, also should be onto the list of emphasized parameters.

It is well-known that phenolic hydroxyl and carbonylic functional groups, which are responsible for the strong adsorption to Cd, are absent from sludge (Lee et al., 1996; Gray et al., 1999). Therefore, Cd mobility usually increases once sludge is amended to soil. It follows that possible environmental risks triggered by $\mathrm{Cd}$ should receive more attention.

The proportion of $\mathrm{Cd}$ in the active fraction was relatively steady and unchanged (Fig. 5). There is a consensus that the proportion of $\mathrm{Cd}$ in the active fraction remains constant during long-term reuse of composted sludge by application to soil (Bergkvist et al., 2005; Tapia et al., 2010), indicating that the pitch point of regulation for active $\mathrm{Cd}$ is not dependent on the change of humus in sludge-amended soil, at least in composted sludge. There are two possible reasons for why active $\mathrm{Cd}$ did not vary. One possibility is that transformation of $\mathrm{Cd}$ fraction occurs in accordance with 'Protect' theory, and is therefore determined by an inorganic ion (salt) functional group rather than the organic fraction. Considering this, active $\mathrm{Cd}$ may exist and behave in a fixed manner. The other possibility is that active $\mathrm{Cd}$ is dependent on the transformation from rapid degradable organic matter to humus, which occurs in and overlaps with a sludge composting period of no $>30$ days. After sludge composting terminated, the amount of active $\mathrm{Cd}$ remained constant, and once composted sludge was sprayed to the soil, slowly
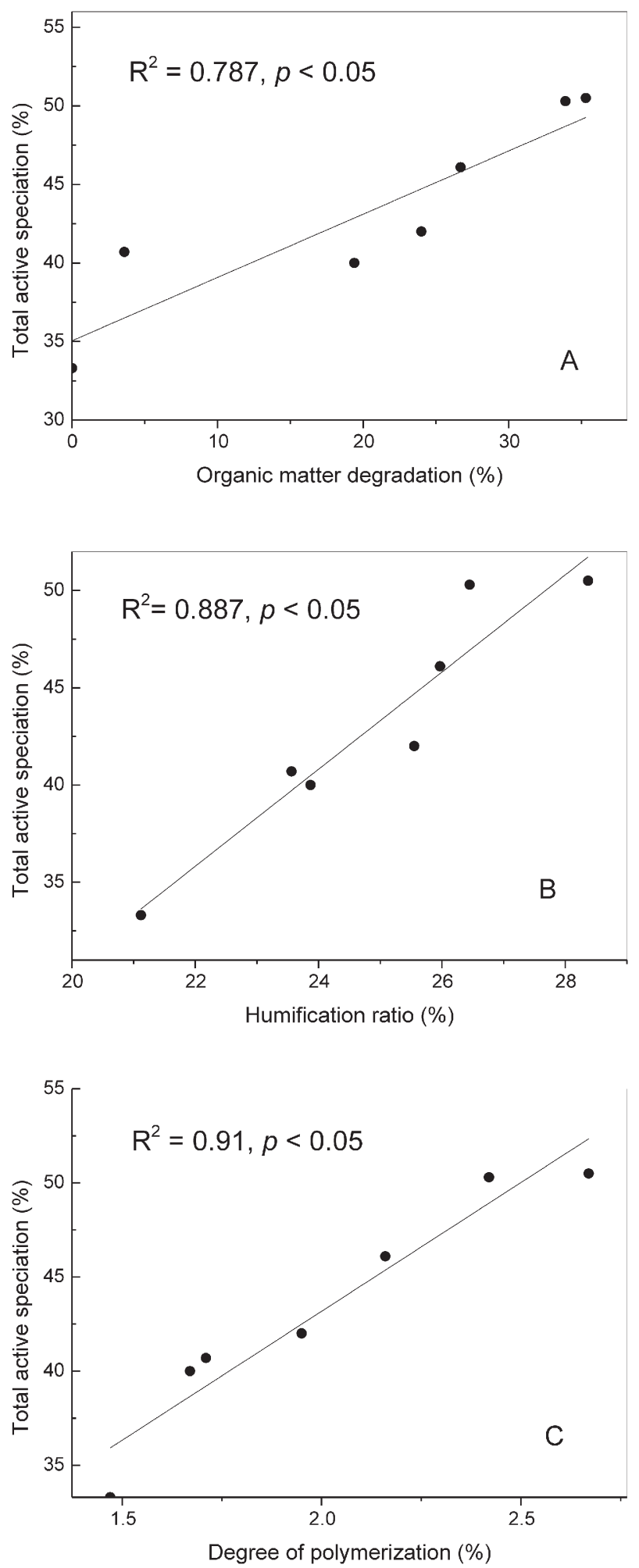

Fig. 6. Linear-regression analyses of the total proportion in the $\mathrm{Cu}$ active fractions and organic matter relative indicators (A: organic matter degradation; B: HR [humification ratio]; C: DP [degree of polymerization]).

degradable organic matter remained dominant, indicating that longterm humification is likely to last for several years. Nevertheless, transformation of $\mathrm{Cd}$ from the inactive fraction to the active fraction was deduced to be regulated by composting process. In sum, these results provide a theoretical framework of availability in sludge-borne $\mathrm{Cu}$ and Cd after application of sludge to soil (Fig. 7). 


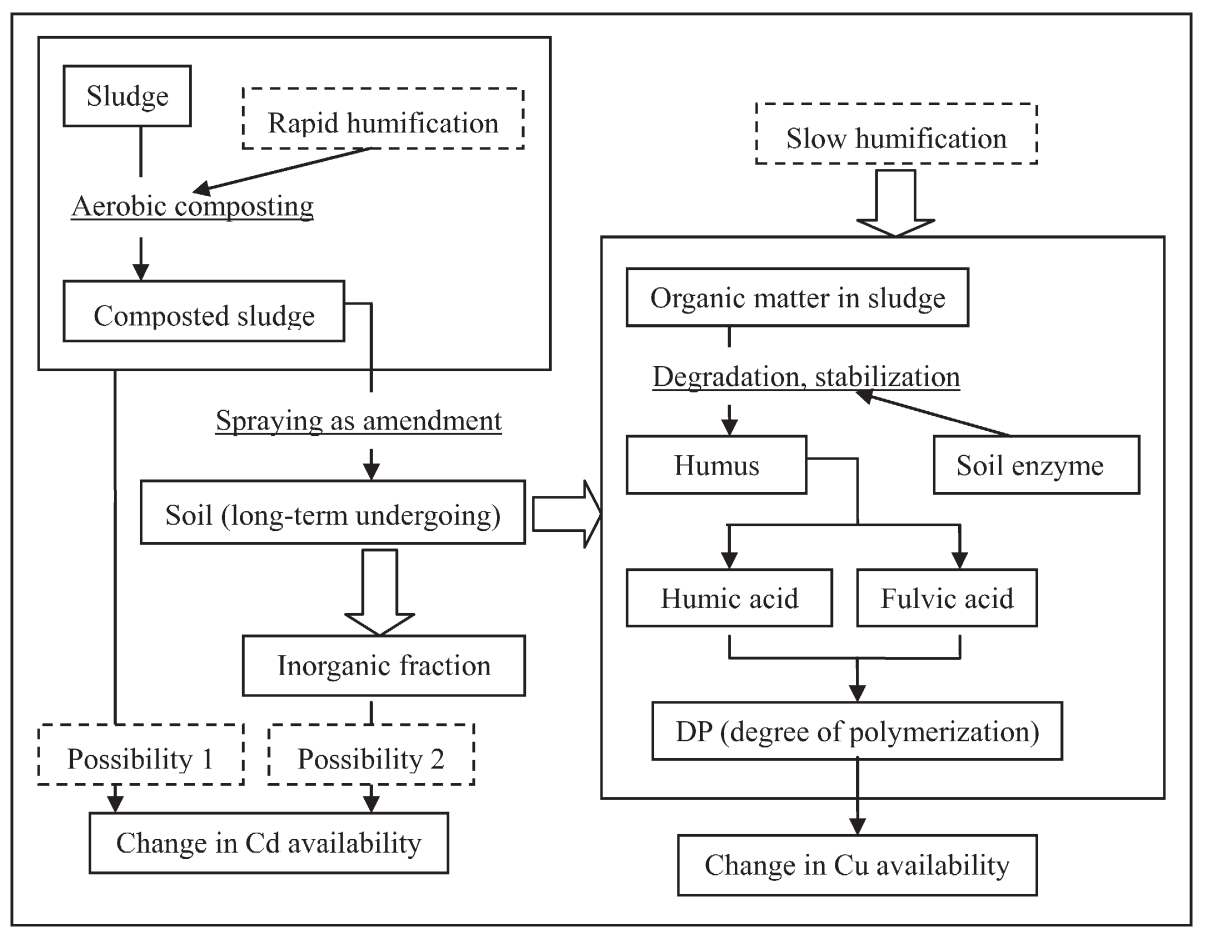

Fig. 7. Theoretical framework of the behavior of sludge-borne $\mathrm{Cu}$ and $\mathrm{Cd}$ after application to soil.

\section{Conclusions}

Previous studies have concluded that bioavailability of heavy metals is associated with organic matter profile. However, these conclusions were based on simulation experiments in the laboratory, and organic matter degradation occurred via chemical oxidation instead of natural processes. The present study presented field monitoring results, which showed that changes in the active fraction of $\mathrm{Cu}$ in sludge better correlated with DP level in sludge rather than organic matter HR and organic matter degradation. However, changes in the active fraction of $\mathrm{Cd}$ were independent of these indicators, remaining almost constant over the 7year experimental period.

\section{Acknowledgements}

The authors acknowledge the financial support from National Natural Science Foundation of China, Beijing Nova Program (Z121109002512061) and Sino-EU Cooperation in Science and Technology Project (Partner Program of China for EU Horizon 2020).

\section{References}

Adani, F., Tambone, F., 2005. Long-term effect of sewage sludge application on soil humic acids. Chemosphere 60, 1214-1221.

Alcantara, S., Perez, D.V., Almeida, M.R.A., Silva, G.M., Polidoro, J.C., Bettiol, W., 2009 Chemical changes and heavy metal partitioning in an oxisol cultivated with maize (Zea mays L.) after 5 years disposal of a domestic and an industrial sewage sludge. Water Air Soil Pollut. 203 (1-4), 3-16.

Antoniadis, V., Tsadilas, C.D., Ashworth, D.J., 2007. Monometal and competitive adsorption of heavy metals by sewage sludge-amended soil. Chemosphere 68 (3), 489-494.

Bergkvist, P., Berggren, D., Jarvis, N., 2005. Cadmium solubility and sorption in a long-term sludge-amended arable soil. J. Environ. Qual. 34, 1530-1538.

Brazauskiene, D.M., Paulauskas, V., Sabiene, N., 2008. Speciation of $\mathrm{Zn}, \mathrm{Cu}$, and $\mathrm{Pb}$ in the soil depending on soil texture and fertilization with sewage sludge compost. J. Soils Sediments 8 (3), 184-192.

Butler, E., Whelan, M.J., Sakrabani, R., van Egmond, R., 2012. Fate of triclosan in field soils receiving sewage sludge. Environ. Pollut. 167, 101-109.

Carbonell, G., Pro, J. Gomez, N., Babin, M.M., Fernandez, C., Alonso, E., Tarazona, J.V., 2009. Sewage sludge applied to agricultural soil: ecotoxicological effects on representative soil organisms. Ecotoxicol. Environ. Saf. 72 (4), 1309-1319.
Diagboya, P.N., Olu-Owolabi, B.I., Adebowale, K.O., 2015. Effects of time, soil organic matter, and iron oxides on the relatice retention and redistribution of lead, cadmium and copper in soils. Environ. Sci. Pollut. Res. 22 (13), 10331-10339.

Fernández, J.M., Hernandez, D., Plaza, C., Polo, A., 2007. Organic matter in degraded agricultural soils amended with composted and thermally-dried sewage sludges. Sci. Total Environ. 378, 75-80.

Frost, H.L., Ketchum, L.H., 2000. Trace metal concentration in durum wheat from application of sewage sludge and commercial fertilizer. Adv. Environ. Res. 4, 347-355.

General Administration of Quality Supervision, Inspection and Quarantine of China, and Standardization Administration of China, 2009a. Disposal of Sludge From Municipal Wastewater Treatment Plant-Control Standards for Agricultural Use (CJ/T3092009). Standards Press of China, Beijing.

Gray, C.W., McLaren, R.G., Roberts, A.H.C., Condon, L.M., 1999. Solubility, sorption and desorption of native and added cadmium in relation to properties of soils in New Zealand. Eur. J. Soil Sci. 50, 127-137.

Lag-Brotons, A., Gomez, I., Navarro-Pedreno, J., Mayoral, A.M., Curt, M.D., 2014. Sewage sludge compost use in bioenergy production-a case study on the effects on Cynara cardunculus L. energy crop. J. Clean. Prod. 79, 32-40.

Lee, S.Z., Allen, H.E., Huang, C.P., Sparks, D.L., Sanders, P.F., Peijnenburg, W.J.G.M., 1996. Predicting soil-water partition coefficients for cadmium. Environ. Sci. Technol. 30, 3418-3424.

Liu, H.T. Zhang, Y., 2013. Key issues on land application of sewage sludge in Chinese national condition. China Water Wastewater 29 (20), 1-4 (In Chinese).

Lu, D.A., Wang, L.X., Yan, B.X., Qu, Y., Guan, J.N., Bian, Y., Zhang, Y.B., 2014. Speciation of Cu and $\mathrm{Zn}$ during composting of pig manure amended with rock phosphate. Waste Manag. 34 (8), 1529-1536.

Mamindy-Pajany, Y., Sayen, S., Mosselemans, J.F.W., Guillon, E., 2014. Copper, nickel and zinc speciation in a biosolid-amended soil: $\mathrm{pH}$ adsorption edge, mu-XRF and muXANES investigations. Environ. Sci. Technol. 48 (13), 7237-7244.

McBride, M.B., 2003. Toxic metals in sewage sludge-amended soils: has promotion of beneficial use discounted the risks? Adv. Environ. Res. 8, 5-19.

Mills, N., Pearce, P., Farrow, J., Thorpe, R.B., Kirkby, N.F., 2014. Environmental \& economic life cycle assessment of current \& future sewage sludge to energy technologies. Waste Manag. 34 (1), 185-195.

Ministry of Housing and Urban-Rural Development of China, 2009. Disposal of Sludge From Municipal Wastewater Treatment Plant-Quality of Sludge Used in Gardens and Parks (GB/T23486-2009).

Ministry of Housing and Urban-Rural Development of China, 2011. Disposal of Sludge From Municipal Wastewater Treatment Plant-Quality of Sludge Used in Forestland (CJ/T362-2011). Standards Press of China, Beijing.

Oladeji, O.O., Tian, G.L., Cox, A.E., Granato, T.C., Pietz, R.I., Carlson, C.R., Abedin, Z., 2012. Effects of long-term application of biosolids for mine land reclamation on groundwater chemistry: trace metals. J. Environ. Qual. 41 (5), 1445-1451.

Oliver, I.W., Hass, A., Merrington, G., Fine, P., Mclaughlin, M.J., 2005. Copper availability in seven Israeli soils incubated with and without biosolids. J. Environ. Qual. 34, 508-513.

Pedra, P. Plaza, C. García-Gil, J.C. Polo, A. 2008. Effects of municipal waste compost and sewage sludge on proton binding behavior of humic acids from Portuguese sandy and clay loam soils. Bioresour. Technol. 99, 2141-2147. 
Rhind, S.M., Kyle, C.E., Ruffie, H., Calmettes, E., Osprey, M., Zhang, Z.L., Hamilton, D., McKenzie, C., 2013. Short- and long-term temporal changes in soil concentrations of selected endocrine disrupting compounds (EDCs) following single or multiple applications of sewage sludge to pastures. Environ. Pollut. 181, 262-270.

Senesi, N., 1989. Composted materials as organic fertilizers. Sci. Total Environ. 81-82, 521-542.

Sims, J.R., Haby, V.A., 1971. Simplified colorimetric determination of soil organic matter Soil Sci. 112, 137-141.

Stanczyk-Mazanek, E., Stepniak, L., Kepa, U., 2009. Degradation of polycyclic aromatic hydrocarbons in soil with sewage sludges. Desalin. Water Treat. 10 (1-3), 158-164.

Stietiya, M.H., Wang, J.J., 2011. Effect of organic matter oxidation on the fractionation of copper, zinc lead, and arsenic in sewage sludge and amended soils. J. Environ. Qual. 40, 1162-1171.

Tessier, A., Campell, P.G.C., Bisson, M., 1979. Sequential extraction procedure for the speciation of particulate trace metals. Anal. Chem. 51, 844-851.
United States Environmental Protection Agency, 1993. CFR 40 Part 503: standards for the use or disposal of sewage sludge. Fed. Regist. 58, 9146.

Wu, J., Zhang, H., He, P.J., Shao, L.M., 2011. Insight into the heavy metal binding potential of dissolved organic matter in MSW leachate using EEM quenching combined with PARAFAC analysis. Water Res. 45 (4), 1711-1719.

Yeganeh, M., Afyuni, M., Khoshgoftarmanesh, A.H., Rezaeinejad, Y., Schulin, R., 2010 Transport of zinc, copper, and lead in a sewage sludge amended calcareous soil Soil Use Manag. 26 (2), 176-182.

Yoshida, H., Christensen, T.H., Scheutz, C., 2013. Life cycle assessment of sewage sludge management: a review. Waste Manag. 31 (11), 1083-1101.

Zheng, G.D., Gao, D., Chen, T.B., Luo, W., 2007. Stabilization of nickel and chromium in sewage sludge during aerobic composting. J. Hazard. Mater. 142 (1-2), 216-221.

Zmora-Nahum, S., Markovitch, O., Tarchitzky, J., Chen, Y.N., 2005. Dissolved organic carbon (DOC) as a parameter of compost maturity. Soil Biol. Biochem. 37, 2109-2116. 